\title{
HUBUNGAN IKLIM KERJA TERHADAP KINERJA PEGAWAI DI LABORATORIUM UNDIKSHA
}

\author{
( Gede Siden Sudaryana1), Ketut Udy Ariawan²) \\ 1,2 Fakultas Teknik dan Kejuruan, Universitas Pendidikan Ganesha \\ Email: ledoenk@gmail.com , udyariawan@undiksha.ac.id
}

\begin{abstract}
ABSTRAK
Penelitian dilakukan dengan tujuan untuk mengetahui hubungan iklim kerja di organisasi/lembaga terhadap kinerja pegawai di Laboratorium Undiksha. Penelitian ini adalah penelitian "ex-post facto", penelitian ini termasuk pendekatan kuantitatif dengan rancangan korelasional. Penelitian ini menggunakan Populasi dan sampel seluruh pegawai di Laboratorium Undiksha yang berjumlah 47 orang pegawai. Dalam penelitian ini variabel bebas iklim kerja $(X)$. Sebagai variabel terikat adalah kinerja pegawai di Laboratorium Undiksha $(Y)$. Untuk pengumpulan data tentang iklim kerja dan kinerja pegawai digunakan kuesioner dengan pola skala likert. Analisis data dilakukan dengan teknik regresi sederhana. Dari Hasil penelitian yang dilakukan, menunjukkan bahwa ada hubungan yang signifikan antara iklim kerja di Laboratorium terhadap kinerja pegawai di Laboratorium Undiksha. Secara normatif ditemukan bahwa iklim kerja berada pada kategori sangat baik. Selain itu, hasil analisis juga menunjukkan bahwa terdapat korelasi yang signifikan antara iklim kerja dengan kinerja pegawai di Laboratorium Undiksha melalui persamaan garis regresi $\hat{y}=0,468$ $+0,940 \mathrm{X}_{3}$ dengan Freg $=41,447(\mathrm{p}<0,05)$. Sedangkan korelasi yang signifikan terjadi antara iklim kerja dengan kinerja pegawai sebesar 0,692 dengan $p<0,05$ dan variabel iklim kerja dapat menjelaskan kinerja pegawai di Laboratorium Undiksha sebesar 47,9\%. Temuan ini mengindikasikan bahwa iklim kerja mempunyai peranan penting dalam meningkatkan kinerja pegawai di Laboratorium Undiksha. Sumbangan efektif (SE) variabel iklim kerja di Laboratorium terhadap kinerja pegawai di Laboratorium Undiksha adalah sebesar 20,59\%.
\end{abstract}

Kata kunci: iklim kerja, kinerja pegawai

\begin{abstract}
The study was conducted with the aim of finding out the relationship of work climate in the organization / institution to the performance of laboratory employees at Undiksha. This research is an "ex-post facto" research, this study includes a quantitative approach with a correlational design. This study uses a population and a sample of all employees in the Undiksha Laboratory, amounting to 47 employees. In this study the work climate free variable $(X)$. As the dependent variable is the performance of Undiksha Laboratory's $(Y)$ employees. For collecting data on work climate and employee performance a questionnaire with a Likert scale pattern was used. Data analysis was performed using a simple regression technique. From the results of research conducted, showed that there is a significant relationship between the work climate in the Laboratory of employee performance in the Undiksha Laboratory. Normatively it is found that the work climate is in the very good category. In addition, the results of the analysis also showed that there was a significant correlation between the work climate and the performance of Laboratory employees at Undiksha through the regression line equation $\hat{y}=0.468+0.940 X 3$ with Freg $=41.474(p<0.05)$. While a significant correlation occurred between work climate and employee performance of 0.692 with $p<0.05$ and work climate variables can explain the performance of Laboratory employees at Undiksha by $47.9 \%$. These findings indicate that the work climate has an important role in improving the performance of Laboratory staff at Undiksha. The effective contribution (SE) of the work climate variable in the Laboratory to the performance of employees in the Undiksha Laboratory is $20.59 \%$.
\end{abstract}

Keywords: work climate, employee performance 


\section{PENDAHULUAN}

Setiap organisasi pemerintah maupun swasta dituntut untuk mengembangkan potensi/kesanggupan Sumber Daya Manusia (SDM) dan mampu beradaptasi dengan berbagai perubahan. SDM sangat peranan penting dalam organisasi, oleh karena itu perlu adanya pemeliharaan hubungan antara pimpinan dan para pegawai bawahan. Keberhasilan kinerja hanya mungkin dilakukan oleh manusia sebaliknya kegagalan, pemborosan dalam berbagai bentuk juga disebabkan oleh manusia. Kuatnya persaingan dalam suatu organisasi yang ada sangat dipengaruhi oleh kinerja para pegawainya.

Seiring dengan adanya otonomi daerah dan desentralisasi serta globalisasi, maka sebuah lembaga perguruan tinggi (PT) diharuskan untuk dapat melaksanakan otonomi kampus, selain itu perguruan tinggi juga dihadapkan pada globalisasi pendidikan yang menuntut institusi bersiap menghadapi persaingan secara global. Salah satu bidang dalam persaingan tersebut adalah jasa pelayanan laboratorium di Perguruan Tinggi. Lembaga Perguruan Tinggi (PT) itu pun harus menghadapi tantangan supaya dapat meningkatkan kualitas SDM agar memiliki skills yang bisa bersaing dengan kompetitor. Hal ini dikarenakan SDM adalah faktor yang sangat penting dalam sebuah organisasi baik dalam skala besar maupun kecil, misalnya saja pada Perguruan Tinggi, SDM dipandang sebagai unsur yang sangat menentukan dalam proses pengembangan dan kemajuan.

Universitas Pendidikan Ganesha memiliki sejumlah pegawai laboratorium yang menjadi bagian dari pegawai di lingkungan Undiksha Singaraja. Pegawai yang menangani laboratorium yang disebut dengan nama laboran/teknisi yang bertugas di laboratorium diharapkan dapat membantu proses belajar mengajar yang efektif dan efisien. Tenaga laboran/teknisi tersebut yang memiliki jabatan fungsional umum dengan kenaikan pangkat setiap 4 tahun sekali. Di lembaga Undiksha, pegawai laboratorium yang ditugaskan di laboratorium sebagian besar sudah sesesuai dengan kualitas tugas yang diembannya. Adapun tugas atau tupoksi (tugas pokok dan fungsi) dari pegawai laboratorium diatur sesuai dengan peraturan bersama.

Selain itu, Pegawai di laboratorium adalah sebagai jabatan fungsional tertentu, dengan atasan langsung pegawai laboratorium adalah Ketua Laboratorium di masing-masing Fakultas. Jenjang karier/kenaikan pangkat pegawai laboratorium didapat dengan perolehan/ pengumpulan angka kredit mereka di laboratorium. Tim penilai untuk jenjang ahli adalah langsung dinilai oleh pemeriksa pusat di Jakarta, sedang jenjang dibawahnya dinilai oleh tim penilai lembaga pendidikan Undiksha dengan jenjang pangkat yang lebih tinggi. Sehingga penilaian untuk jenjang terampil adalah tugas dari tim Penilai Angka Kredit (PAK) tingkat pegawai laboratorium ahli, dan diketahui oleh kepala laboratorium.

Yang merupakan unsur paling penting mempengaruhi kualitas seorang pegawai adalah kinerja kerja pegawai. Kinerja adalah tingkat terhadapnya para pegawai mencapai persyaratan pekerjaan secara efisien dan efektif. Kinerja merupakan prestasi kerja pegawai, yaitu perbandingan antara hasil pekerjaan yang dapat dilihat secara nyata dengan standarisasi kerja yang telah ditetapkan organisasi.

Berdasarkan pengertian-pengertian kinerja pegawai dari beberapa pendapat, dapat dibuat disimpulan bahwa kinerja merupakan hasil kerja baik secara kualitas maupun kuantitas yang sudah dicapai oleh pegawai, dalam menjalankan tugas-tugas yang diberikan sesuai dengan tanggung jawab yang telah diberikan oleh organisasi, dan hasil kerja pegawai tersebut disesuaikan dengan hasil kerja yang diharapkan organisasi, melalui kriteria atau standar-standar kinerja pegawai yang diberlakukan dalam organisasi.

Orang yang mempunyai kinerja tinggi sesuai denga karakteristik sebagai berikut: (1) Mempunyai tanggung jawab pribadi yang tinggi. (2) Berani bertindak dan menanggung resiko yang dihadapi. (3) Mempunyai tujuan yang realistis. (4) Mempunyai rencana kerja yang luas/menyeluruh dan berjuang untuk merealisasikan tujuannya. (5) Seluruh kegiatan kerja yang dilakukan dengan memanfaatkan umpan balik (feed back) yang konkrit. (6) Mencari kesempatan untuk merealisasikan rencana yang telah diprogramkan [7].

Secara individu Ada lima indikator kinerja pegawai, yang dapat dijelaskan sebagai berikut: (1) Kualitas, merupakan tingkatan dimana, aktivitas yang dilakukan mendekati sempurna dalam artian menyesuaikan beberapa cara ideal dari penampilan aktivitas dan memenuhi tujuan yang diharapkan dari suatu aktivitas. (2) Kuantitas, merupakan banyaknya jumlah dihasil yang biasanya dinyatakan dalam istilah jumlah unit, jumlah siklus aktivitas yang diselesaikan. (3) Ketepatan Waktu, adalah tingkat aktivitas yang telah diselesaikan pada waktu awal yang diinginkan dilihat dari sudut koordinasi hasil output serta memaksimalkan waktu yang telah ditersediakan untuk aktivitas orang lain. (4) Efektivitas, merupakan tingkat pengguna Sumber Daya Manusia dalam organisasi dengan tujuan menaikkan keuntungan dan mengurangi kerugian dari setiap unit dalam pengguna sumber daya manusia. (5) Kinerja Kerja, merupakan tingkat dimana pegawai mempunyai Kinerja kerja dengan organisasi dan bertanggung jawab kepada organisasi. 
Untuk mereview kinerja pegawai, peringkat kerja pegawai, penilaian kinerja pegawai, penilaian pegawai, dan sekaligus mengevaluasi pegawai sehingga dapat diketahui pegawai yang mampu melaksanakan pekerjaan secara baik, efisien, efektif dan produktif sesuai dengan tujuan dipergunakan Instrumen penilaian Kinerja Ipegawai. Kinerja pegawai adalah hal yang mutlak penting dalam upaya perusahaan untuk mencapai tujuannya.

Ada beberapa aspek yang mempengaruhi kinerja pegawai, diantaranya iklim kerja. Iklim Kerja adalah gambaran tentang situasi, suasana dan karakter yang terlihat pada norma dan nilai, hubungan interpersonal, situasi suasana belajar-mengajar, struktur organisasi yang ada, ikatan positif dengan lembaga dan lingkungan fisik yang terdapat di lembaga tempat pegawai ditugaskan. Yang perlu dicermati adalah setiap lembaga/organisasi memiliki iklim kerja yang berbeda-beda. Rancang pekerjana yang beraneka ragam di dalam organisasi, atau sifat individu yang akan menggambarkan perbedaan tersebut.

Iklim kerja akan mempengaruhi perilaku setiap anggotanya, dimana kualitas lingkungan internal secara relatif yang dialami oleh anggota lembaga organisasi akan terus berlangsung. Iklim kerja sangat perpengaruh dalami pelaksanan dan kebijakan SDM yang diterima oleh anggota organisasi. Sangat perlu untuk diketahui bahwa dimana setiap organisasi/lembaga akan memiliki iklim kerja yang berbeda. Rancangan keanekaragaman pekerjaan dalam organisasi inilah yang akan menggambarkan perbedaan tersebut.

Setiap organisasi memiliki strategi sendiri-sendiri dalam mengelola SDM. Dengan keterbukaan Iklim akan membuat kebebasan pegawai untuk mengutarakan kepentingan dan ketidakpuasan dalam lembaga/organisasi tanpa adanya rasa takut dan tidak puas terhadap atasan dalam organisasi tersebut, dan ketidakpuasan seperti harus ditangani dengan cara yang positif dan bijaksana. Iklim keterbukaan akan tercipta bila organisasi mempunyai keyakinan yang tinggi dan mempercayai keadilan untuk semua anggota. Iklim Kerja yang dilakukan dalam organisasi sangat penting untuk diciptakan karena dapat dijadikan dasar bagi penentuan tingkah laku anggota selanjutnya yang mempunyai persepsi tentang apa yang telah diberikan organisasi. Seberapa baik anggota diarahkan, dibangun dan hargai oleh organisasi akan menentukan keadaan Iklim dari organisasi tersebut. Dari berbagai macam pemahaman tentang iklim kerja didapat bahwa iklim kerja berkaitan erat dengan : lingkungan dalam organisasi internal, individu yang ada dalam organisasi, dan karakteristik yang khas antar organisasi. Gambaran secara umum Pengukuran Iklim Kerja dapat diartikan sebagai pengukuran dari kepribadian individu.

Adapun lingkungan internal yang dimaksud adalah lingkungan dalam organisasi tersebut dan aktifitas organisasi yang dilakukan. Misalnya dengan mengobservasi terhadap rapat yang diadakan, dokumen-dokumen yang tersimpan, surat menyurat, nota dan bahkan interpretasi lisan maupun tertuis misalnya seperti telepon kantor yang harus selalu dikunci. Dengan demikian Deskripsi ini akan memberikan gambaran organisasi yang konservatif, otoriter, demokratis, ataupun non komunikatif. Selain itu bisa juga informasi tersebut dengan melalui orang-orang yang ada dalam organisasi tersebut, misalkan orang akan merasakan iklim kerja yang nyaman atau tidak yang diberikan lembaga /organisasi dalam hal menerima atau menolak peraturan, kaidah-kaidah dan bagaimana mereka memandang lingkungan sosial dalam organisasi.Dari berbagai pendapat dapat disimpulkan bahwa konsep iklim kerja yaitu dalam hal melaksanakan pekerjaan atau aktifitas, prilaku orang-orang yang ada dalam suatu organisasi sangat dipengaruhi oleh situasi lingkungan tempat mereka bekerja.

Di masyarakat umum Iklim kerja sangatlah memegang peran penting untuk menyediakan SDM yang efektip sehingga menjauhkan lembaga/ organisasi dari hal-hal negatif dan dapat merangsang hal positip untuk terus bekerja dengan teamework untuk menghasilkan tujuan dan cita-cita organisasi/perusahaan.

Semakin banyak hal/unsur pekerjaan yang sesuai dengan keinginan dan sistem nilai yang diterapkan pada individu, maka tingkat kepuasan yang didapat semakin tinggi. Begitu juga sebaliknya, semakin banyak hal/unsur pekerjaan yang tidak sesuai dengan keinginan dari sistem nilai yang dianut individu, mak kepuasan yang didapat semakin rendah. Kepuasan kerja adalah cara pandang para pekerja untuk memandang pekerjaan mereka dengan perasaan yang menyenangkan. Kepuasan kerja adalah cermin perasaan seseorang terhadap pekerjaannya yang terlihat dari sikap pegawai terhadap pekerjaan dan segala sesuatu yang berada di lingkungan kerjaannya. Semua jenis lembaga dan organisasi sebenarnya membutuhkan suatu sistem kerja yang secara serius harus memperhatikan hal kepuasan kerja para pegawainya.

Hal ini sejalan dengan penelitian yang dilakukan oleh Rahsel dengan judul "Pengaruh Iklim Kerja Terhadap Kinerja Pegawai Administrasi Pusat Universitas Padjadjaran Bandung (Studi Pada Bagian Administrasi Umum UNPAD)" [9]. Dimana penelitian dan hasil hipotesis yang dilakukan Rahsel menyatakan bahwa ada pengaruh positif dari iklim/situasi kerja terhadap kinerja yang dilakukan 
pegawai. Hasil analisa berdasarkan tabel Anova menunjukkan bahwa ada pengaruh antara iklim kerja dengan kinerja pegawai pada bagian Administrasi Kepegawaian Umum UNPAD Bandung, yang menyatakan bahwa hipotesis penelitian dapat diterima dan terbukti kebenarannya. Rekomendasi yang diberikan penulis adalah agar terus meningkatkan kinerja pegawai pada bagian Administrasi Umum UNPAD. Hal ini dapat diwujudkan melalui kondusifnya iklim kerja yang diperlukan agar tercipta hubungan dan komunikasi yang baik, hal ini diyakini dan membuka peluang bagi pegawai dalam memberikan kinerja yang tinggi [9].Saat ini banyak pegawai di laboratorium yang kurang memiliki motivasi yang tinggi saat bekerja, sehingga berdampak pada iklim kerja yang kurang kondusip. Hal ini dapat dilihat dengan menurunnya kualitas kerja pegawai di laboratorium Undiksha. Mungkin hal tersebut disebabkan oleh adanya para pegawai laboratorium yang tidak memiliki kinerja, dan kurangnya perhatian dari atasan atau pimpinan atas kinerja para pegawai laboratorium. Kurangnya reward yang diberikan oleh lembaga kepada para pegawai laboratorium juga berdampak pada kinerja para pegawai laboratorium.

Tidak jarang pegawai laboratorium dan teknisi ditempatkan pada tempat yang salah, menyebabkan kompetensi yang mereka miliki tidak sesuai ditempat mereka bekerja, sehingga tidak jarang menurunkan motivasi kerja mereka akibat tempat mereka bekerja tidak sesuai lagi dengan kompetensi yang mereka miliki. Keadaan seperti ini akan menyebabkan berkurangnya tanggung jawab mereka terbadap pekerjaan yang mereka kerjakan, dimana nantinya akan menguragi kinerja mereka sebagai pegawai laboratorium.

Dari latar belakang di atas, maka peneliti ingin membahas lebih jauh tentang adanya pengaruh iklim kerja terhadap kinerja kerja pegawai di Laboratorium lingkungan lembaga Undiksha yang pada akhirnya dapat berdampak pada peningkatan kinerja para pegawai tersebut, karena di laboratorium Undiksha, rata-rata pegawai selalu mempunyai masa kerja di atas 5 tahun dan jarang adanya keluar masuk pegawai. Tentunya hal ini menjadi hal yang strategis untuk diteliti, sehingga pegawai memiliki kinerja yang cukup tinggi. Penelitian dilakukan dengan tujuan untuk menguji apakah terdapat hubungan iklim kerja dengan kinerja pegawai di laboratorium Undiksha.

\section{METODE PENELITIAN}

Penelitian ini termasuk penelitian non-treatment atau ex-post facto karena tidak dilakukan perlakuan pada variabel dan hanya mengambil data secara langsung. Lebih lanjut, penelitian ini termasuk pendekatan kuantitatif dengan rancangan korelasional karena dalam penelitian ini mencoba mengetahui hubungan yang ada antar variabel yang dikorelasikan [6]. Hasil penelitian hanyalah mendeskripsikan dan menganalisis adanya hubungan antara iklim kerja dengan kinerja pegawai di Laboratorium Undiksha.

Populasi adalah keseluruhan objek dalam suatu penelitian [1]. Populasi merupakan generalisasi wilayah yang ditetapkan peneliti yang terdiri atas subjek dan objek berkualitas yang mempunyai karakteristik tertentu untuk dipelajari kemudian ditarik simpulannya [11]. Pendapat lainnya oleh Ridwan dalam Buchari, populasi adalah keseluruhan dari karakteristik atau unit hasil pengukuran yang menjadi objek penelitian [4].Dari pendapat-pendapat tersebut disimpulkan bahwa populasi adalah subjek atau objek yang menjadi pusat penelitian yang berisikan syarat-syarat tertentu yang berhubungan dengan masalah penelitian dalam suatu wilayah. Dalam penelitian ini Populasinya adalah seluruh pegawai di Laboratorium Undiksha yang berjumlah 47 pegawai.

Tabel 1. Populasi Penelitian

\begin{tabular}{ccc}
\hline No. & Fakultas & Jumlah \\
\hline 1. & FMIPA & 9 Orang \\
2. & FTK & 11 Orang \\
3. & FBS & 9 Orang \\
4. & FOK & 2 Orang \\
5. & FIS & 7 Orang \\
6. & FIP & 4 Orang \\
7. & FEB & 5 Orang \\
& Jumlah & 47 Orang \\
\hline
\end{tabular}

(Sumber: Data Kepegawaian Undiksha)

Menurut Agung sebagian dari populasi yang diambil dalam hal ini adalah disebut sampel, yang dianggap mewakili seluruh populasi dan diambil dengan menggunakan teknik tertentu [1]. Sedangkan menurut Sugiyono, sampel distilahkan bagian dari jumlah dan karakteristik yang dimiliki oleh populasi 
[11]. Berdasarkan pendapat pendapat tersebut dapat ditarik simpulan bahwa sampel adalah bagian dari populasi dengan karakteristik yang dimiliki sama dengan populasi. Pengambilan sampel hendaknya representatif sehingga hasil kajian pada sampel dapat digeneralisasi pada populasi.

Menurut Buchari, terdapat beberapa keuntungan jika penelitian mengunakan sampel antara lain: (1) memudahkan penelitian dibandingkan menggunakan populasi yang jumlahnya jauh lebih besar, (2) penelitian lebih efesien (penghematan uang, tenaga, dan waktu), (3) penggunaan sampel lebih teliti dan cermat dalam pengumpulan data, (4) penelitian lebih efektif, terutama jika penelitian sifatnya merusak misalnya mengetahui adanya bakteri dalam tubuh pasien [4].

Teknik penentuan sampel dalam penelitian ini menggunakan sampling sensus atau jenuh. Sampling sensus atau sampling jenuh menurut Sugiyono adalah adalah teknik penentuan sampel dimana semua anggota populasi digunakan sebagai sampel [11]. Berdasarkan dari pengertian tersebut, maka dapat diketahui bahwa sampling sensus atau jenuh adalah teknik penentuan sampel dengan menggunakan seluruh populasi, yaitu berjumlah 47 pegawai laboratorium.

Tabel 2. Sampel Penelitian

\begin{tabular}{ccc}
\hline No. & Fakultas & Jumlah \\
\hline 1. & FMIPA & 9 Orang \\
2. & FTK & 11 Orang \\
3. & FBS & 9 Orang \\
4. & FOK & 2 Orang \\
5. & FIS & 7 Orang \\
6. & FIP & 4 Orang \\
7. & FEB & 5 Orang \\
& Jumlah & 47 Orang \\
\hline
\end{tabular}

Variabel-variabel yang digunakan dalam penelitian ini adalah variabel bebas (independent variable) dan variabel terikat (dependent variable). Variabel bebas $(\mathrm{X})$ yaitu variabel yang mempengaruhi variabel terikat. Sedangkan variabel terikat $(Y)$ merupakan variabel yang dipengaruhi akibat adanya variabel bebas. Dalam penelitian ini variabel bebas iklim kerja $(X)$, dan sebagai variabel terikat adalah kinerja pegawai di Laboratorium Undiksha $(\mathrm{Y})$.

Konstalasi variabel penelitian dapat digambarkan seperti gambar 01 di bawah ini.

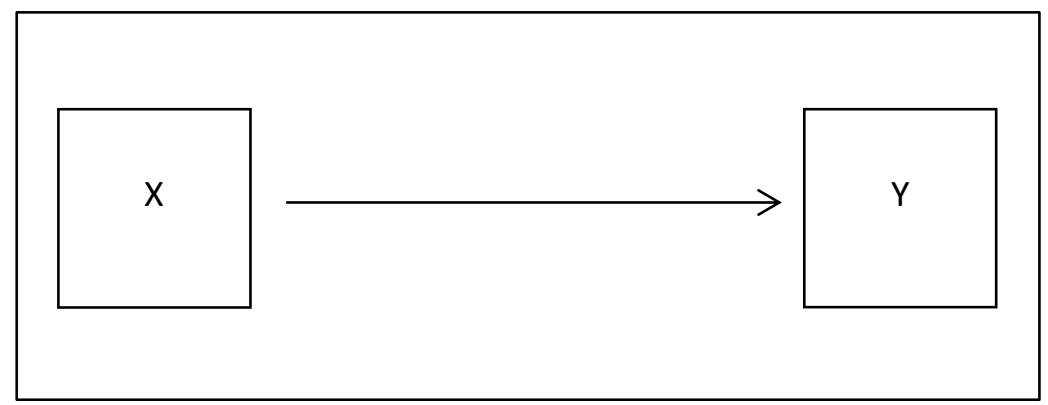

Gambar 1. Konstelasi Hubungan Variabel Bebas dengan Variabel Terikat

Keterangan:

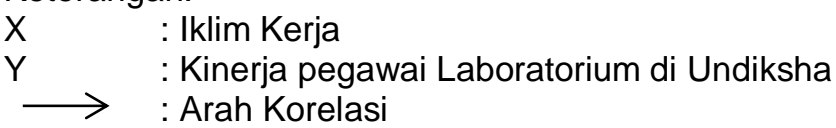

Kemudian variabel-variabel tersebut didefinisikan secara konseptual dan operasional.

Definisi konseptual Iklim Kerja pegawai $(X)$, merupakan suasana kerja yang ada pada suatu lembaga yang dirasakan oleh semua pegawai, yang menggambarkan kehidupan yang terjadi dalam lembaga tersebut, dan Definisi Konseptual Kinerja kerja $(Y)$ adalah suatu keterikatan antara tugas dan kewajiban pegawai yang dapat membentuk tanggung jawab serta sikap responsif dan inovatif dalam menjalankan tugas.

Sedangkan Definisi operasional Iklim kerja (work climate) $(\mathrm{X})$ adalah suasana kerja di tempat mereka bekerja dengan ditandai adanya tindakan-tindakan, tradisi-tradisi dan pelaksanaan kerja dari 
personalia tersebut yang dilandasi rasa tanggung jawab dan kepuasan kerja. Menurut Depdiknas (2000) bahwa iklim kerja pada sebuah lembaga dibagi menjadi tiga bagian yaitu: Pertama iklim kerja secara fisik ini meliputi beberapa indikator seperti (1) keamanan, (2) kebersihan, (3) kesehatan, (4) ketertiban, (5) kerindangan, (6) kesejukan, (7) keindahan. Kedua konsiderasi yaitu (1) sikap atasan, (2) pertimbangan, (3) keakraban, (4) motivasi. Ketiga Iklim kerja yang ditinjau dari perilaku pegawai dan definisi operasional Kinerja pegawai merupakan keinginan yang kuat dari semua anggota organisasi untuk mengikatkan diri dalam suatu organisasi secara suka rela dan berusaha keras untuk kepentingan organisasi, yang dijabarkan kedalam tiga dimensi Kinerja dalam berorganisasi, yaitu : affective, continuance, dan normative. Ketiga hal tersebut lebih tepat dinyatakan sebagai komponen dari Kinerja kerja dalam sebuah lembaga/organisasi.

Untuk pengumpulan data tentang iklim kerja dan kinerja pegawai digunakan kuesioner dengan pola skala likert. Sementara itu, pendapat Riduwan menyatakan bahwa "angket (questionnaire) adalah daftar yang berisikan pertanyaan diberikan kepada orang lain yang bersedia memberi respons (responden) jawaban sesuai dengan permintaan pengguna" [10]. Sedangkan untuk memperoleh banyaknya pegawai Laboratorium yang ada dimasing-masing bagian digunakan metode dokumen, serta metode observasi sebagai metode pelengkap .

Alat pengumpul data harus memenuhi persyaratan, yaitu syarat validitas dan reliabilitas dalam mengungkap data-data yang akan diukur. Ada dua persyaratan yang hendak digunakan dalam pengumpulan data penelitian, yaitu validitas dan reliabilitas [5]. Validitas instrumen yang digunakan pada penelitian ini meliputi dua segi yaitu validitas isi dan validitas butir. Validitas isi dibantu oleh dua orang ahli/ expert, kemudian dianalisis dengan teknik Gregory.

Dipandang perlu untuk diuji terlebih dahulu validitas dari masing-masing pertanyaan yang ada sebelum instrumen digunakan sebagai alat pengambilan data. Dengan demikian diadakan uji coba terlebih dahulu terhadap kuisioner dan hasilnya ini dianalisis. Untuk menguji validitas butir rumusan yang digunakan adalah dengan rumus hubungan product moment dari Pearson [2].

Pengujian terhadap reabilitas instrumen dilakukan melalui pendekatan ketetapan internal. Uji reliabilitas adalah ketepatan dan keajegan alat pengukur yang digunakan dalam menilai apa yang diinginkan, artinya kapan pun alat tersebut digunakan akan diperoleh hasil yang sama [8]. Pengujian reliabilitas dengan menggunakan rumus Alpha dari Crombach [2].

Kegiatan analisis data terdiri atas kegiatan pengolahan data dan analisis statistik. Kegiatan menganalisis data meliputi: 1) menyunting data dengan cara manual. Kemungkinan dilakukan penyuntingan data dikarenakan ada data yang tidak jelas, atau kesalahan pengisian instrument, sehingga tidak dapat dianalisis karena tidak memenuhi syarat, 2) membuat tabulasi data, dan 3) mengolah data sesuai kebutuhan.

Hipotesis yang telah dirumuskan, diuji terlebih dahulu dengan melakukan analisis data yang telah dikumpulkan. Dalam melakukan analisis data untuk penelitian ini dilakukan dengan tiga tahapan yakni: 1) tahap deskripsi data, 2) tahap pengujian persyarat analisis, 3) tahap pengujian hipotesis.

Data yang telah diperoleh dari penelitian dideskripsikan menurut masing-masing variabel, yaitu skor variabel iklim kerja $(X)$ dan skor variabel kinerja pegawai $(Y)$. Selanjutnya dicari harga rerata $(M)$, standar deviasi (SD), modus (Mo) dan median (Me) setiap variabel yang diteliti. Untuk tujuan tersebut, sebelum dicari harga-harga yang diperlukan akan dibuat terlebih dahulu tabel distribusi frekuensi interval. Untuk melihat kecenderungan variabel, rata-rata skor ideal dari semua subjek penelitian dibandingkan dengan rata-rata kenyataan. Dari rerata tersebut dikelompokkan kecenderungannya menjadi lima kategori dengan norma kerangka teoritik kurve normal ideal.

Dengan memperhatikan skor terendah dan tertinggi ideal, maka skor rata-rata ideal $(\mathrm{Mi})=1 / 2$

(skor maksimal+skor minimum) dan (SDi) Standar Deviasi ideal = 1/6 (skor maksimal - skor minimum). Atas dasar nilai rata-rata ideal dan standar deviasi ideal, dapat disusun peringkat ordinal, yaitu dengan jalan membandingkan rata-rata obeservasi dengan seperti yang telah disusun diatas.

Setelah data dideskripsikan, maka analisis dilanjutkan dengan menggunakan teknik regresi sederhana, persyaratan yang berkaitan dengan teknik analisis data tersebut harus dibuktikan secara statistik.

Setelah seluruh uji prasyarat terpenuhi, maka dilanjutkan dengan uji hipotesis. Pengujian hipotesis penelitian ini mengunakan teknik analisis korelasi sederhana (korelasi product moment pearson). Untuk menganalisis uji hipotesis yang dilakukan dalam penelitian ini digunakan program SPSS-17.00 for windows. 


\section{HASIL PENELITIAN DAN PEMBAHASAN}

Hasil pembahasan yang mencakup deskripsi dan karakteristik variabel-variabel penelitian, uraian hasil pengujian persyaratan analisis dan uji hipotesis. Hasil penelitian yang dimaksud adalah menyangkut deskripsi data tentang iklim kerja $(\mathrm{X})$, dan Kinerja pegawai $(\mathrm{Y})$ Laboratorium di Undiksha. Hasil perhitungan seperti Tabel 03 didapatkan berdasarkan hasil analisis data yang telah dilakukan oleh peneliti.

Tabel 3. Rangkuman Statistik Dari Variabel Iklim Kerja dan Kinerja Pegawai

\begin{tabular}{ccc}
\hline Variabel & $\mathbf{X}$ & $\mathbf{Y}$ \\
\hline Statistik & 47 & 47 \\
Jumlah Sampel & 44,276 & 136,127 \\
Rata-rata & 1443 & 135 \\
Median & 143 & 135 \\
Modus & 143 & 11,732 \\
Standar Deviasi & 8,639 & 137,636 \\
Ragam & 74,639 & 44 \\
Rentangan & 30 & 115 \\
Skor Minimum & 130 & 159 \\
Skor Maksimum & 160 & 6398 \\
Jumlah & 6781 & \\
\hline
\end{tabular}

\footnotetext{
Keterangan :

$\mathrm{X}=$ Iklim kerja

$\mathrm{Y} \quad=$ Kinerja pegawai
}

Data variabel iklim kerja yang didapat dari hasil pengukuran terhadap responden menunjukkan bahwa skor tertinggi yang dicapai adalah 160 dari skor tertinggi yang mungkin dicapai, yaitu 175, sedangkan skor terendah yang dicapai adalah 130 dari skor terendah yang mungkin dicapai, yaitu 35 .

Tabel 4. Distribusi Frekuensi Skor Variabel Iklim Kerja

\begin{tabular}{|c|c|c|c|c|}
\hline No & \multicolumn{2}{|c|}{ Kelas interval } & Nilai tengah & Frekuensi Absolute \\
\hline 1 & 130 & -134 & 132 & 9 \\
\hline 2 & 135 & -139 & 137 & 7 \\
\hline 3 & 140 & -144 & 142 & 8 \\
\hline 4 & 145 & -149 & 147 & 12 \\
\hline 5 & 150 & -154 & 152 & 3 \\
\hline 6 & 155 & -159 & 157 & 7 \\
\hline \multirow[t]{2}{*}{7} & 160 & -164 & 162 & 1 \\
\hline & & & & 47 \\
\hline
\end{tabular}

Dari Tabel 04, di atas dapat dilihat bahwa pengelompokan frekuensi dari variabel iklim kerja $(X)$ terletak di sekitar nilai rata-rata sebesar $25,53 \%$. Agar lebih mempermudah dalam hal pembacaan tabel di atas, akan lebih jelas disajikan dalam bentuk grafik histogram distribusi frekuensi variabel, seperti tampak pada berikut: 


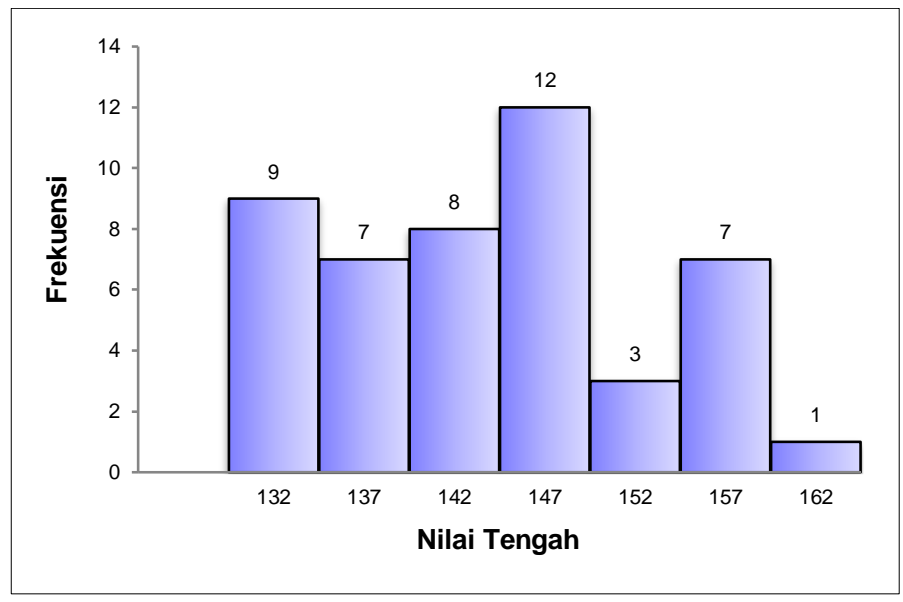

Gambar 2. Histogram Variabel Iklim Kerja

Dari hasil perhitungan tendensi sentral diperoleh harga rata-rata sebesar 144,28 , simpangan baku sebesar 8,64, varians sebesar 74,64, modus sebesar 143 , dan median sebesar 143 . Untuk menyusun Tabel konversi dalam menentukan kategorisasi skor variabel iklim kerja akan dihitung terlebih yaitu, mean ideal (MI) kemudian Standar Deviasi ideal. $\mathrm{Ml}=1 / 2 \times$ (skor maks ideal + skor min ideal $)=1 / 2 \times(175+35)=105$. SDi $=1 / 6 \times($ skor maks ideal - skor min ideal $)=1 / 6 \times(175-35)=$ 23,33 .

Secara umum skor rata-rata iklim kerja pegawai Laboratorium di Undiksha diperoleh sebesar 144,28 dengan simpangan baku (standar deviasi) sebesar 8,64. Hasil ini menunjukkan bahwa kecenderungan iklim kerja pegawai Laboratorium di Undiksha dapat dikategorikan sangat baik, yaitu berada pada rentangan 139,995 $\leq$ X dari skor ideal.

Data variabel kinerja pegawai yang didapat dari hasil pengukuran terhadap responden menunjukkan bahwa skor paling tinggi yang dicapai adalah 159 dari skor tertinggi yang mungkin dicapai yaitu 165, sedangkan skor paling rendah yang dicapai adalah 115 dari skor terendah yang mungkin dapat dicapai yaitu 33 .

Tabel 5. Distribusi Frekuensi Skor Variabel Kinerja Pegawai

\begin{tabular}{|c|c|c|c|c|}
\hline \multirow{2}{*}{$\begin{array}{l}\text { No } \\
1\end{array}$} & \multicolumn{2}{|c|}{ Kelas interval } & \multirow{2}{*}{$\begin{array}{c}\begin{array}{c}\text { Nilai } \\
\text { tengah }\end{array} \\
118 \\
\end{array}$} & \multirow{2}{*}{$\begin{array}{c}\begin{array}{c}\text { Frekuens } \\
\text { Absolute }\end{array} \\
7\end{array}$} \\
\hline & 115 & - 121 & & \\
\hline 2 & 122 & - $\quad 128$ & 125 & 5 \\
\hline 3 & 129 & - 135 & 132 & 12 \\
\hline 4 & 136 & - 142 & 139 & 10 \\
\hline 5 & 143 & - 149 & 146 & 7 \\
\hline 6 & 150 & - 156 & 153 & 3 \\
\hline \multirow[t]{2}{*}{7} & 157 & - 163 & 160 & 3 \\
\hline & & & & 47 \\
\hline
\end{tabular}

Pada Tabel diatas, dapat diamati berdasarkan pengelompokan frekuensi variabel kinerja pegawai $(Y)$ terletak disekitar skor rata-rata dengan frekuensi sebesar 17,95\%. Untuk lebih mempermudah dalam membaca tabel di atas, berikut akan lebih jelas bila disajikan grafik histogram distribusi frekuensi variabel, seperti ditampilkan pada gambar berikut: 


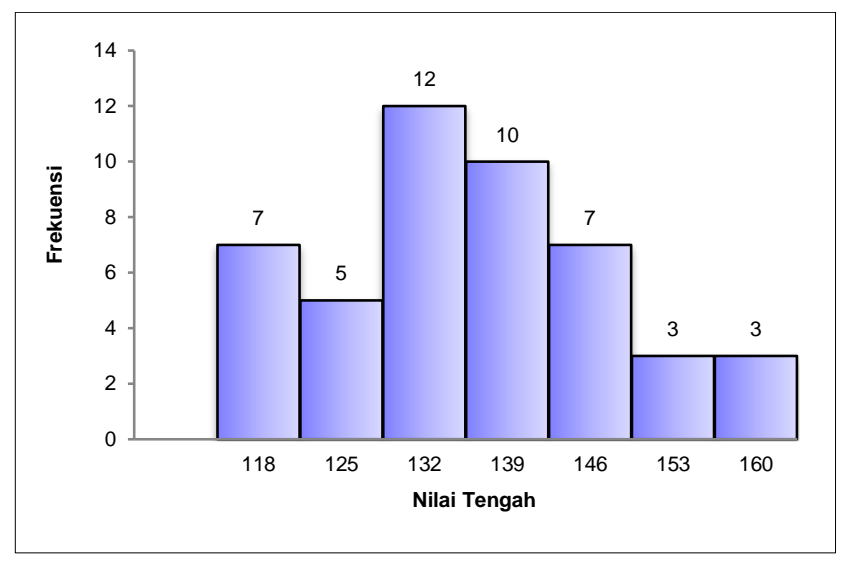

Gambar 3. Histogram Variabel Kinerja Pegawai

Hasil perhitungan tendensi sentral dari variabel kinerja pegawai harga rata-rata sebesar 136,13, simpangan baku sebesar 11,73, varians sebesar 137,64, modus sebesar 135, dan median sebesar 135. Untuk menyusun Tabel konversi dalam menentukan kategorisasi skor variabel kinerja pegawai terlebih dahulu dihitung mean ideal (MI) dan standar deviasi ideal (SDi). $\mathrm{MI}=1 / 2 \times$ (skor maksimal ideal + skor minimal ideal $)=1 / 2 \times(165+33)=99$. SDi $=1 / 6 \times($ skor maksimal ideal - skor minimal ideal $)=$ $1 / 6 \times(165-33)=22$.

Secara umum skor rata-rata kinerja pegawai Laboratorium di Undiksha diperoleh sebesar 136,13 dengan simpangan baku (standar deviasi) sebesar 11,73. Hasil ini menunjukkan bahwa kecenderungan kinerja pegawai Laboratorium di Undiksha dapat dikategorikan sangat baik, yaitu berada pada rentangan $132 \leq$ dari skor ideal.

Secara normatif ditemukan bahwa iklim kerja berada pada kategori sangat baik. Selain itu, hasil analisis juga menunjukkan bahwa terdapat korelasi yang signifikan antara iklim kerja dengan kinerja pegawai Laboratorium di Undiksha melalui persamaan garis regresi $\hat{y}=0,468+0,940 X_{3}$ dengan Freg $=41,447(\mathrm{p}<0,05)$. Sedangkan korelasi yang signifikan terjadi antara iklim kerja dengan kinerja pegawai sebesar 0,692 dengan $p<0,05$ dan variabel iklim kerja dapat menjelaskan kinerja pegawai Laboratorium di Undiksha sebesar $47,9 \%$. Temuan ini mengindikasikan bahwa iklim kerja mempunyai peranan penting dalam meningkatkan kinerja pegawai Laboratorium di Undiksha. Sumbangan efektif (SE) untuk variabel iklim kerja dan variabel kinerja pegawai Laboratorium di Undiksha adalah sebesar $20,59 \%$.

Hasil penelitian yang sejalan dengan hasil penelitian ini dilakukan oleh Mangkunegara dengan judul Effect of Work Discipline, Work Motivation and Job Satisfaction on Employee Organizational Commitment in the Company (Case Study in PT. Dada Indonesia) [7]. Dimana dinyatakan pada Penelitian ini bahwa pengaruh Disiplin Kerja, Motivasi Kerja dan Kepuasan Kerja terhadap Komitmen kerja para pekerjanya pada level kepegawaian. Sedangkan objek penelitian adalah staf karyawan di PT. Dada Indonesia. Adapun masalahnya mengacu pada fenomena tingkat absensi pada PT. Dada Indonesia yang rata-rata mencapai 4-5 persen. Sehingga memunculkan masalah yaitu: bagaimana cara meningkatkan Komitmen kerja Organisasi dengan menggunakan 4 (empat) hipotesis penelitian yang telah dirumuskan menggunakan Proportional Random Sampling dan menggunakan 148 responden dan keseluruhan staf adalah karyawan PT (Persero) Dada Indonesia, dimana hasil penelitian ini menunjukkan bahwa Disiplin Kerja berpengaruh positif terhadap Komitmen kerja Organisasi. [7]

Iklim kerja adalah suasana di tempat kelompok itu berada yang memberikan perasaan bahwa semua anggota dilingkungan kerja mereka semuanya dianggap setara. Pengertian mengiartikan bahwa suasana kerja yang baik jika dalam suatu organisasi kerja dapat memberi perasaan senang kepada semua anggota organisasi dan tidak ada perbedaan perlakuan atau pemberian perlakuan yang istimewa pada salah satu anggota organisasi. Dengan demikian, dengan iklim kerja yang bagus dan harmonis maka akan menciptakan iklim dan keadaan kerja yang kondusip sehingga dapat berdampak pada kinerja kerja pegawai yang baik.

Pegawai yang mempunyai iklim kerja yang bagus dan tidak hanya untuk kepentingan dirinya, akan dapat melakukan tugas dengan tepat, sesuai dengan profesinya sebagai pegawai. Sehingga iklim kerja berhubungan secara signifikan terhadap kinerja pegawai di Laboratorium Undiksha. Berdasarkan pemaparan di atas, maka dapat disimpulkan bahwa iklim kerja memberikan hubungan yang signifikan terhadap kinerja pegawai di Laboratorium Undiksha. 


\section{SIMPULAN DAN SARAN}

Dengan demikian dari hasil penelitian dan pembahasan yang telah dilakukan, maka dapat ditarik simpulan adanya hubungan yang signifikan antara iklim kerja terhadap kinerja pegawai di Laboratorium Undiksha dengan koefisien korelasi sebesar 0,692 dan sumbangan efektifnya sebesar $20,59 \%$. berikut.

Berdasarkan hasil dan kesimpulan dari penelitian ini, dapat diajukan beberapa saran sebagai

1. Bagi Pimpinan

Pimpinan hendaknya mampu untuk meningkatkan iklim kerja pegawainya dan mampu memfasilitasi tercapainya iklim kerja yang kondusif bagi para pegawainya, karena perannya yang sangat strategis dan sangat penting bagi pencapaian misi, visi dan tujuan suatu organisasi selain itu merupakan salah satu motif yang mendorong manusia untuk selalu menyelidiki seluk beluk yang terkait dengan kinerjanya.

2. Bagi Pegawai Laboratorium

Pegawai laboratorium hendaknya mampu untuk meningkatkan iklim kerja serta kinerja kerja yang dimiliki sehingga dapat meningkatkan kualitas pelayanan di Laboratorium pada lembaga.

3. Bagi Peneliti Lain

Peneliti lain diharapkan mampu mengembangkan variabel lain dalam usaha meningkatkan kinerja pegawai di Laboratorium, sehingga dapat memberikan hubungan pengetahuan yang lebih luas.

\section{DAFTAR PUSTAKA}

[1] Agung, A A Gede. 2014. Metodologi Penelitian Pendidikan. Yogyakarta: Aditya Media Publishing.

[2] Arikunto, Suharsimi. 1995. Manajemen Penelitian. Jakarta: Rineka Cipta.

[3] Arikunto, Suharsimi. 1997. Prosedur Penelitian Suatu Pendekatan Praktek. Jakarta: Rineka Cipta.

[4] Buchari, Alma. 2009. Manajemen Pemasaran dan Pemasaran Jasa, Cetakan kedelapan. Bandung: Alfabeta.

[5] Hamzah, B. Uno. 2007. Teori Motivasi dan Pengukurannya. Jakarta: Bumi Aksana.

[6] Koyan, I Wayan. 2012. Statistik Pendidikan. Singaraja: Universitas Pendidikan Ganesha Press.

[7] Mangkunegara, A.P. 2015. Effect of Work Discipline, Work Motivation and Job Satisfaction on Employee Organizational Commitment in the Company (Case Study in PT. Dada Indonesia). Universal Journal of Management 3(8): 318-328, 2015.

[8] Puger, I Gusti Ngurah. 2004. Belajar Kooperatif. Diktat Perkuliahan Mahasiswa Unipas.

[9] Rahsel, Yoeyong. 2016. Pengaruh Iklim Kerja Terhadap Kinerja Pegawai Administrasi Pusat Universitas Padjadjaran Bandung (Studi Pada Bagian Administrasi Umum UNPAD). Jurnal Manajemen Magister, Vol 02. No.01, Januari 2016.

[10]Riduwan. 2005. Skala Pengukuran Variabel-variabel Penelitian. Bandung: Alfabeta.

[11]Sugiyono. 2008. Metode Penelitian pedidikan pendekatan kuantitatif, kualitatif, dan R\&D. Bandung: Alfabeta.

[12] Sugiyono. 2009. Statistika Untuk Penelitian. Bandung: Alfabeta. 